\title{
Model Discovery Learning Berbantuan Media Lingkungan Mempengaruhi Hasil Belajar
}

\author{
Rahayu Made Chandenni \\ Program Studi Pendidikan Guru Sekolah Dasar, Universitas Pendidikan Ganesha, Singaraja, Indonesia
}

\begin{abstract}
Abstrak
Penelitiann ini bertujuan untuk menelaah pengaruh penerapan model discovery learning berbantuan media lingkungan terhadap hasil belajar IPA siswa kelas IV SD Gugus Yos Sudarso Kecamatan Denpasar Selatan Tahun Ajaran 2019/2020. Hasil dari uji normalitas dengan menggunakan kolmogorov smirnov untuk rata-rata hasil belajar pengetahuan IPA siswa kelompok eksperimen $\bar{X}=20,811$ lebih besar daripada rata-rata hasil belajar pengetahuan IPA siswa kelompok kontrol $\overline{\mathrm{X}}=18,032$. Data yang diperoleh dianalisis menggunakan teknik analisis uji-t dengan rumus polled varians. Hasil analisis data diperoleh (thitung= 3,518 $>$ ttabel $=1,997$ ) pada taraf signifikasi $5 \%(\mathrm{dk}=37+31-2=66)$ maka, H0 ditolak dan Ha diterima yang berarti terdapat perbedaan yang signifikan hasil belajar pengetahuan IPA antara kelompok siswa yang dibelajarkan dengan model discovery learning berbantuan media lingkungan dengan kelompok siswa yang dibelajarkan dengan pembelajaran konvensional pada siswa kelas IV SD Gugus Yos Sudarso Kecamatan Denpasar Selatan Tahun Ajaran 2019/2020. Dengan demikian dapat disimpulkan bahwa model discovery learning dengan berbantuan media lingkungan berpengaruh terhadap hasil belajar pengetahuan dalam pembelajaran IPA Kelas IV SD Gugus Yos Sudarso Kecamatan Denpasar Selatan Tahun Ajaran 2019/2020.
\end{abstract}

Kata Kunci:

Discovery Learning,

Hasil Belajar, IPA

\begin{abstract}
This study aims to determine the effect of the application of discovery learning models assisted by environmental media on the learning outcomes of science class IV students of the SD Sudarso Cluster, South Denpasar District, Academic Year 2019/2020. The results of the normality test using Kolmogorov Smirnov for the average science learning outcomes of students in the experimental group $\bar{X}=20,811$ are greater than the average learning outcomes of the science knowledge of the control group students $\overline{\mathrm{X}}=18,032$. The data obtained were analyzed using the t-test analysis technique with the polled variance formula. The results of data analysis were obtained (tcount $=3.518>$ ttable $=1.997)$ at the significance level of $5 \%(\mathrm{dk}=37+31$ - $2=66$ ) then, H0 was rejected and Ha was accepted, which means there was a significant difference in the learning outcomes of science knowledge between groups of students who learning with discovery learning models assisted by environmental media with groups of students who are taught with conventional learning in fourth grade students of SD Sudarso Cluster, South Denpasar District, Academic Year $2019 / 2020$. Thus it can be concluded that the discovery learning model with the help of environmental media influences the learning outcomes of knowledge in learning Natural Sciences Class IV SD Sudoso Cluster South Denpasar District Academic Year $2019 / 2020$.
\end{abstract}

Keywords:

Discovery Learning, Learning outcomes, Science 


\section{PENDAHULUAN}

Kurikulum merupakan panduan atau pedoman dalam melaksanakan pendidikan di sekolah sehingga kurikulum sangat mempengaruhi pihak-pihak komponen sekolah secara langsung maupun tidak langsung diantaranya yakni pihak kepala sekolah, guru, pengawas sekolah, orangtua siswa, bahkan siswa itu sendiri, serta masyarakat di lingkungan sekitar sekolah. Dalam mengimplementasikan kurikulum 2013 terdapat beberapa hal yang perlu diperhatikan dan sedikit berbeda dengan kurikulum sebelumnya, karena kurikulum 2013 ini menitik beratkan adanya penekanan pada kompetensi siswa atau kemampuan yang harus dicapai siswa, ini sangatlah berbeda dengan kurikulum yang sebelumnya, serta media yang digunakan masih banyak kekurangan karena belum sesuai dengan materi serta penilaianya sangat kompleks dan penggunaan metodenya harus sesuai dengan materi yang disampaikan sehingga guru harus bisa lebih kreatif dalam mengimplementasikan pembelajaran agar tercapainya tujuan pembelajaran, maka penerapan pada kurikulum sebelumnya sering kali peranan pendidik tidak sebagai fasilitator melainkan sebagai sumber belajar, sedangkan siswa hanya sebagai objek melainkan tidak sebagai subjek.

Pada penerapan kurikulum 2013 seorang pendidik yang profesional dituntut untuk dapat menampilkan keahliannya di depan kelas. Kegiatan proses belajar mengajar di kelas guru selalu ingin menemukan metode dan peralatan baru yang dapat memberikan semangat belajar bagi semua siswa. Bahkan secara keseluruhan dapat dikatakan bahwa pembaharuan dalam sistem pendidikan yang mencangkup seluruh komponen yang ada. Kualitas pendidikan merupakan suatu masalah yang kursial dalam bidang pendidikan yang sedang dihadapi oleh negara - negara berkembang, karena kualitas pendidikan yang dimiliki suatu negara merupakan cerminan dari kualitas negara bersangkutan (Sugiyastini \& dkk, 2013).

Salah satu masalah yang dihadapi dalam kaidah dunia pendidikan di Indonesia adalah lemahnya proses pembelajaran. Dewasa ini, kemampuan berpikirlah yang menjadi tolak ukur pengembangan sumber daya manusia di suatu daerah. Proses pembelajaran yang terjadi di kelas, siswa hanya ditekankan untuk menghafal, mengingat berbagai informasi oleh pendidik. Proses pembelajaran tersebut seakan berbanding terbalik dengan kualitas sumber daya manusia yang dibutuhkan.

Berdasarkan Peraturan Pemerintahan No. 19 Tahun 2005 Bab 1 ayat 6, standar proses pendidikan adalah standar nasional pendidikan yang berkaitan dengan pelaksanaan pembelajaran pada satuan pendidikan untuk mencapai standar kompetensi kelulusan. Proses pendidikan tersebut dibagi menjadi standar kompetensi kelulusan, standar isi, standar pendidik, tenaga pendidik, standar pengelolaan, standar sarana dan prasarana. Pembelajaran dari pendidik harus dikemas, dari memilih model dan metode yang tepat untuk membuat siswa aktif dalam pembelajaran. Jika pendidik hanya menggunakan satu metode seperti metode ceramah atau model pembelajaran konvensional dimana pembelajaran hanya berpusat kepada pendidik dan siswa hanya sebagai pendengar. Pembelajaran dengan metode - metode lama seperti itu sangat tidak efektif digunakan dalam pembelajaran sekarang yang sudah menggunakan kurikulum 2013 dimana siswa dituntut aktif dalam pembelajaran dan pendidik harus menyiapkan model dan metode pembelajaran yang bervariasi dalam setiap pembelajaran sehingga membuat siswa tidak cepat bosan dalam pembelajaran dan nantinya akan membuat hasil belajar pengetahuan siswa juga meningkat. Hal yang terpenting untuk mewujudkan proses pendidikan yang baik tidak terlepas dari pemilihan model pembelajaran. Peraturan Menteri Pendidikan dan Kebudayaan Republik Indonesia nomor 103 tahun 2014 tentang pembelajaran pada pendidikan dasar dan menengah disebutkan bahwa pada implementasi kurikulum 2013 sangat disarankan menggunakan berbagai macam model pembelajaran dalam melaksankan pembelajaran di kelas, sehingga guru itu dituntut untuk meningkatkan kompetensi diri, lebih inovatif dalam memilih dan menggunakan model pembelajaran agar siswa lebih aktif dalam mengikuti pembelajaran di kelas.

Berdasarkan dari latar belakang tersebut, jelaslah bahwa dalam proses pembelajaran siswa dituntut untuk mencari tahu, bukan diberitahu dan penggunaan bahasa yang tepat harus dilakukan untuk mengkomunikasikan materi pembelajaran yang akan disampaikan, disamping itu pendekatan saintifik dapat mendorong kreatifitas siswa untuk mencari tahu sesuatu, berfikir logic dan sistematis serta dibutuhkan model pembelajaran yang relevan.

Discovery learning dipandang sebagai suatu model pembelajaran. Hal ini tercantum dari pernyataan yang ada pada lampiran IV Peraturan Menteri Pendidikan dan Kebudayaan Republik Indonesia nomor 103 tahun 2014 BAB IV tentang pembelajaran pada pendidik dasar dan menengah disebutkan bahwa pada implementasi Kurikulum 2013 sangat disarankan menggunakan discovery learning. Pada setiap model tersebut dapat dikembangkan sikap, pengetahuan, dan keterampilan.

Model pembelajaran yang diterapkan kepada siswa memiliki skenario pembelajaran untuk memecahkan masalah yang nyata. Dalam memecahkan masalah mereka selalu menggunakan pengalaman mereka terdahulu sebagai perbandingan dalam menyelesaikan masalah. Dalam upaya menemukan 
sesuatu mereka berinteraksi untuk menggali, mempertanyakan selama bereksperimen dengan rasa ingin tahu siswa yang tinggi. Model discovery learning merupakan model pembelajaran yang melibatkan peserta didik untuk belajar mengenali masalah, solusi, mencari informasi yang relevan, mengembangkan strategi solusi, dan melaksanakan strategi yang dipilih. Model discovery learning pengetahuan yang diperoleh siswa akan lama diingat, konsep - konsep jadi lebih mudah diterapkan pada situasi baru dan meningkatkan penalaran siswa menurut (Nurdin \& Andriantoni, 2016:212).

Pada penelitian di SD Gugus Yos Sudarso akan diterapkan model discovery learning dengan berbantuan media lingkungan dalam muatan pembelajaran IPA di kelas IV. Semua lingkungan yang ada di sekitar kita bisa digunakan sebagai media pembelajaran (Efendi, 2013).

Sedikit pendidik yang menerapkan model discovery learning berbantuan media lingkungan. Begitu juga muatan pembelajaran IPA (Ilmu Pengetahuan Alam). Berdasarkan hasil wawancara teridentifikasi masalah seperti : (1) siswa hanya ditekankan untuk menghafal dan mengingat berbagai informasi, (2) kurang bervariasinya model yang digunakan oleh guru di kelas, (3) partisipasi siswa dalam pembelajaran IPA masih kurang aktif, (4) kompetensi pengetahuan IPA masih kurang. Menurut mereka, dalam pembelajaran tersebut, model ini masih terasa asing dan jarang sekali digunakan sebelumnya, sehingga sulit mendapatkan konsep yang tepat dalam merancang dan melaksanakan pembelajaran dengan model discovery learning tersebut.

Belajar di lingkungan dapat menjadi sarana memupuk kreatifitas inisiatif kemandirian, kerja sama atau gotong royong dan meningkatkan minat pada pelajaran (Susilowati, 2010:4-15). Dengan mengajak siswa belajar di luar kelas siswa akan melihat peristiwa langsung di lapangan dengan tujuan untuk mengakrabkan siswa dengan lingkungannya. Berdasarkan hal tersebut maka dirancang penelitian yang berjudul "Pengaruh Model Discovery Learning Berbantuan Media Lingkungan Terhadap Hasil Belajar IPA Siswa Kelas IV Gugus Yos Sudarso Kecamatan Denpasar Selatan Tahun Ajaran 2019/2020".

\section{METODE PENELITIAN}

Pelaksanaan penelitian dimulai dari Januari 2020 sampai dengan Maret 2020. Gugus Yos Sudarso Kecamatan Denpasar Selatan menjadi tempat dilaksanakannya penelitian. Adapun seluruh SD yang tergabung di Gugus Yos Sudarso Kecamatan Denpasar Selatan yaitu SD Negeri 2 Sanur, SD Negeri 5 Sanur, SD Negeri 6 Sanur, SD Negeri 10 Sanur, SD Negeri 12 Sanur. Menetapkan lokasi penelitian bertujuan untuk memudahkan penulis untuk melaksanakan kegiatan penelitian dan penelitian ini dilakukan di beberapa SD yang ada dalam Gugus Yos Sudarso Kecamatan Denpasar Selatan.

Jenis penelitian yang dilakukan dalam penelitian ini yaitu penelitian kuantitatif dengan desain eksperimental yaitu quasi eksperiment (Eksperimen Semu) yang bertujuan untuk mengontrol variabelvariabel luar namun tidak semuanya bisa terpengaruhi. Hal tersebut disebabkan karena adanya keterbatasan peneliti untuk mengamati perilaku siswa ketika siswa berada di luar sekolah atau dirumah, selain itu peneliti tidak dapat mengetahui persepsi siswa terhadap perlakuan secara pasti.

Kelompok yang mendapatkan perlakuan adalah kelompok yang dieksperimenkan menggunakan model discovery learning berbantuan media lingkungan sedangkan kelompok kontrol adalah kelompok yang diberikan pembelajaran dengan kegiatan pembelajaran secara konvensional. Pada penelitian ini menggunakan rancangan yang diformulasikan dengan desain "Nonequivalent Post-Test Only Control Group Design" (Sugiyono, 2018:116).. Pada rancangan penelitian ini tujuan pemberian pre-test pada kelompok biasanya digunakan untuk mengukur ekuivalensi atau penyetaraan kelompok (Sugiyono, 2018:116). Untuk melakukan penyetaraan kelompok dapat dilakukan teknik uji-t. Selanjutnya peneliti memberikan perlakuan kepada kelompok eksperimen dengan model discovery learning dan memberikan pembelajaran secara konvensional kepada kelompok kontrol.

Populasi data dalam suatu penelitian adalah bagian yang penting. Penentuan populasi secara tepat menjadi penting untuk menghindari bias dalam penelitian. Bias penelitian sangat perlu dihindari agar hasil penelitian dapat sesuai tujuan yaitu mempresentasikan kondisi yang sesungguhnya dari obyek penelitian.

Populasi merupakan segala sesuatu yang mencakup atas obyek dan subyek yang memiliki tingkat karakteristik tertentu yang ditetapkan oleh peneliti untuk dipelajari. Jadi populasi tidak hanya orang saja, melainkan obyek dan benda - benda alam di sekitarnya. Populasi bukan hanya jumlah yang ada pada obyek atau subyek termasuk seluruh karakteristik atau sifat yang dimiliki oleh subyek maupun obyek itu (Sugiyono, 2018:117).

Dapat disimpulkan pengertian populasi adalah keseluruhan obyek yang dijadikan kajian dalam penelitian. Populasi dalam penelitian ini dapat dirinci melalui Tabel sebagai berikut. 
Tabel 1. Data Kelas IV SD Gugus Yos Sudarso Tahun Ajaran 2019/2020

\begin{tabular}{llll}
\hline No & Sekolah & Kelas & Jumlah Siswa \\
\hline 1 & SD Negeri 10 Sanur & IV & 88 \\
\hline 2 & SD Negeri 5 Sanur & IV & 37 \\
\hline 3 & SD Negeri 12 Sanur & IV & 31 \\
\hline 4 & SD Negeri 2 Sanur & IV & 40 \\
\hline 5 & SD Negeri 6 Sanur & IV & 35 \\
\hline Jumlah & & & $\mathbf{2 3 1}$ \\
\hline
\end{tabular}

Berdasarkan hasil observasi yang dilaksanakan peneliti pada masing-masing SD kelas IV di dalam Gugus Yos Sudarso bahwa kelas IV dari 5 sekolah dari Gugus Yos Sudarso memiliki kemampuan yang tidak setara. Apabila dikatakan setara, jika pengelompokan siswa itu memiliki kemampuan yang sama dari 5 sekolah yang ada.

Setelah menentukan populasi selanjutnya menentukan sampel dalam penelitian. Di dalam sampel ditentukan oleh peneliti baik dari jumlah dan karakteristik yang dimiliki oleh populasi tersebut (Sugiyono, 2011:81). Sedangkan menurut (Setyosari, 2015:221) Sampel itu mencerminkan dan menentukan tingkat kualitas yang dimiliki sampel dalam menarik suatu kesimpulan pada sebuah penelitian. Jadi dapat disimpulkan bahwa sampel merupakan bagian dari populasi yang mewakili anggota populasi untuk dijadikan sebagai data penelitian.

Pada penelitian ini digunakan teknik Random Sampling dan yang dirandom adalah kelas. Penentuan sampel pada penelitian ini dilakukan melalui pengacakan kelas bukan pengacakan individu. Sebelum pengacakan kelas untuk dijadikan sampel, terlebih dahulu mengundi semua nama kelas IV di seluruh sekolah dasar yang ada di SD Gugus Yos Sudarso. Setelah kedua kelas yang terpilih maka dilakukan uji kesetaran untuk mengetahui tingkat kesetaraan kedua kelas yang dijadikan kelompok eksperimen dan kelompok kontrol. Kedua sampel diberi pre-test agar dalam perhitungan uji kesetaraan benar diketahui bahwa kemampuan kedua sampel relative sama. Setelah memperoleh skor dari hasil pre-test tersebut selanjutnya dilakukan uji kesetaraan melalui uji prasyarat yang meliputi uji normalitas sebaran data dan uji homogenitas dengan teknik Kolmogorov-Smirnov dan homogenitas varians dengan uji Fisher $(F)$. Berikut ini hasil rekapitulasi uji normalitas sebaran data pada sampel penelitian hasil belajar pengetahuan IPA dijabarkan pada tabel dibawah ini.

Tabel 2. Rekapitulasi Uji Normalitas Sebaran Data Pada Sampel Penelitian Hasil Belajar Pengetahuan IPA

\begin{tabular}{llllll}
\hline No. & Sampel & $\begin{array}{l}\text { Banyak } \\
\text { Sampel }\end{array}$ & $\begin{array}{l}\text { Nilai } \\
\text { Maksimum } \\
\mid \text { Ft-Fs } \mid\end{array}$ & $\begin{array}{l}\text { Nilai Tabel } \\
\text { Kolmogorov- } \\
\text { Smirnov }\end{array}$ & Keterangan \\
\hline 1 & Sampel Eksperimen & 37 & 0,13 & 0,21 & Berdistribusi Normal \\
\hline 2 & Sampel Kontrol & 31 & 0,10 & 0,23 & Berdistribusi Normal \\
\hline
\end{tabular}

Berikut ini hasil rekapitulasi uji homogenitas varians kelas eksperimen pada sampel penelitian hasil belajar pengetahuan IPA dijabarkan pada tabel dibawah ini.

Tabel 3. Rekapitulasi Uji Homogenitas Varians Kelas Eksperimen dan Kelas Kontrol

\begin{tabular}{lllllll}
\hline No. & Sampel & $\mathbf{S}^{\mathbf{2}}$ (Varian) & Dk & F $_{\text {hitung }}$ & F $_{\text {tabel }}$ & Keterangan \\
\hline 1 & Sampel Eksperimen & 10,15 & 36 & & \multirow{2}{*}{1,06} & Homogen \\
\hline 2 & Sampel Kontrol & 10,83 & 30 & & \\
\hline
\end{tabular}

Dari uraian tabel diatas harga $F_{\text {hitung }}<F_{\text {tabel }}(1,06<1,78)$, maka varians data hasil pretest hasil belajar pengetahuan IPA pemahaman antara kelas IV SD Negeri 5 Sanur dan kelas IV SD Negeri 12 Sanur adalah homogen. Dilanjutkan dengan uji-t yaitu untuk menguji kelompok tersebut setara atau tidak dijabarkan pada tabel dibawah ini.

Berdasarkan hasil uji-t diperoleh bahwa kedua kelompok tersebut setara dengan hasil analisis menunjukkan nilai $t_{\text {hitung }}=3,51$ untuk $d k=(n 1+n 2)-2=66$ dengan taraf signifikansi $5 \%$ diperoleh $t_{\text {tabel }}=$ 
1,99 sehingga $t_{\text {hitung }}<t_{\text {tabel }}$ maka Ho diterima, yang artinya kedua kelompok setara. Setelah kedua kelompok kelas sampel setara kemudian dilanjutkan pengundian kelompok kelas eksperimen dan kelompok kelas kontrol dengan hasil kelas IV SD Negeri 5 Sanur sebagai kelompok kelas eksperimen dan kelas IV SD Negeri 12 Sanur sebagai kelompok kelas kontrol.

Tabel 4. Rekapitulasi Uji Kesetaraan Sampel Menggunakan Uji-t

\begin{tabular}{llcccc}
\hline No. & Sampel Penelitian & $\mathbf{t}_{\text {hitung }}$ & Dk & $\mathbf{t}_{\text {tabel }}$ & Keterangan \\
\hline 1 & Kelas IV SD Negeri 5 Sanur & 3,51 & 66 & 1,99 & Tidak Setara \\
\hline 2 & Kelas IV SD Negeri 12 Sanur & & & \\
\hline
\end{tabular}

Dalam penelitian ini, teknik pengumpulan data yang digunakan untuk mengukur hasil belajar siswa adalah dengan menggunakan metode tes yaitu untuk mengukur hasil belajar IPA siswa. Peneliti mengumpulkan data sesuai dengan keperluan penelitian. "Pengumpulan data ini menuturkan bagaimana data peneliti itu diperoleh" (Setyosari, 2015:247). Menurut Agung (2014) "Metode tes dalam kaitannya dengan penelitian ini ialah cara memperoleh data yang berbentuk suatu soal yang harus dikerjakan oleh seorang atau sekelompok orang yang dites (tastee) dan dari tes dapat menghasilkan skor".

Dalam sebuah pelaksanaan penelitian terdapat variabel yang akan diteliti. Menurut Sugiyono (2017:2) "Variabel merupakan segala sesuatu yang berbentuk apa saja yang ditetapkan oleh peneliti untuk dipelajari sehingga memperolah tentang hal tersebut, kemudian ditarik kesimpulannya". Sedangkan menurut Setyosari (2015:162) "Variabel atau faktor secara umum adalah segala sesuatu yang akan menjadi objek pengamatan dalam penelitian dan jika diukur memiliki variasi".

Jadi dapat disimpulkan variabel adalah objek yang dipilih oleh peneliti sebagai titik fokus perhatian dalam suatu penelitian. Pada penelitian ini menggunakan 2 variabel, yaitu variabel bebas (independent) dan varibel terikat (dependent) yang dijelaskan sebagai berikut.

Jadi dapat dirangkum variabel bebas adalah variabel yang mempengaruhi yang menjadi sebab munculnya variabel terikat. Variabel bebas dalam penelitian ini adalah Model discovery learning Berbantuan media lingkungan menjadi pelaku dalam kelompok eksperimen sedangkan pembelajaran konvensional dikenakan pada kelompok kontrol.

Kisi-kisi instrumen merupakan pedoman atau panduan dalam merumuskan pertanyaanpertanyaan instrumen yang diturunkan dari variabel evaluasi yang akan diamati. Dalam kisi-kisi terdapat variabel yang diteliti, indikator sebagai tolak ukur dan nomer butir (item) pertanyaan atau pernyataan yang telah dijabarkan dari indikator (Sugiyono, 2015:353). Sehingga peneliti memiliki gambaran yang jelas tentang jenis instrumen dan isi dari butir - butir yang akan disusun. Jenis instrumen yang digunakan pada penelitian ini berupa tes objektif. Sebelum instrumen digunakan di dalam penelitian, terlebih dahulu akan dilakukan pengujian instrumen baik dari segi konten atau isi maupun empirisnya. Instrumen yang digunakan dalam penelitian ini diuji coba melalui uji validitas, uji reliabilitas, daya beda, tingkat kesukaran.

Uji validitas berkaitan dengan ketetapan alat ukur instrumen. Pengertian umum untuk validitas item adalah demikian sebuah item dikatakan valid apabila mempunyai dukungan yang besar terhadap skor total Arikunto (2016:90). Untuk mengukur validitas butir tes kompetensi pengetahuan IPA dalam bentuk pilihan ganda (objektif) digunakan teknik korelasi product moment. Setelah perhitungan

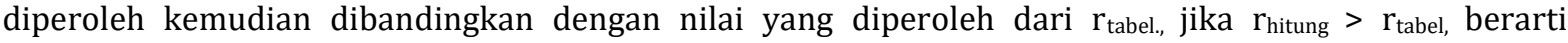
instrumen tersebut dapat dinyatakan valid dan jika $r_{\text {hitung }} \leq r_{\text {tabel }}$ berarti instrumen tersebut dapat dinyatakan tidak valid.Berdasarkan perhitungan tersebut, dari 50 butir tes yang diujikan diperoleh hasil 30 butir tes yang valid dan 20 butir tes yang tidak valid.

Uji reliabilitas dilakukan terhadap butir soal yang valid saja, dengan demikian uji reliabilitas bisa dilakukan setelah dilakukannya uji validitas. Reliabilitas dalam suatu penelitian berhubungan dengan masalah kepercayaan. Menurut Arikunto (2015:100) suatu tes dapat dikatakan mempunyai taraf kepercayaan yang tinggi jika test tersebut dapat memberikan hasil yang tetap.Uji reliabilitas hanya dilakukan pada butir soal yang valid saja. Sehingga uji reliabilitas dapat dilakukan setelah melalui uji validitas. Uji relibialitas tes yang bersifat di (objektif) dan heterogen ditentukan dengan rumus Kuder Richardshon (KR-20).

Kemudia dalam pemberian interpretasi terhadap koefesien reliabilitas tes $r_{11}$ pada umumnya digunakan patokan yakni apabila $r_{11} \geq 0.70$ berarti tes yang sedang diuji reliabilitasnya dinyatakan telah reliable dan apabila $\mathrm{r}_{11}<0.70$ berarti tes yang sedang diuji reliabilitasnya dinyatakan unreliable. 
Berdasarkan hasil perhitungan terhadap 30 butir tes yang dinyatakan valid dan memiliki daya pembeda cukup dan baik. Kriteria butir tes reliable atau tidak, apabila $\mathrm{r}_{11}>0,70$ berarti tes yang sedang diuji dinyatakan reliabel. Dari perhitungan diperoleh nilai $r=0,90>0,70$, dengan demikian tes hasil belajar IPA dinyatakan reliabel.

Tingkat kesukaran tes adalah tingkat kesulitan tes untuk dijawab oleh responden. Taraf kesukaran tes merupakan perbandingan antara peserta tes yang menjawab benar dan jumlah seluruh responden. "Soal yang baik adalah soal yang tidak terlalu mudah atau tidak terlalu sukar. Soal yang terlalu mudah tidak merangsang siswa untuk mempertinggi usaha memecahkannya. Sebaliknya soal yang terlalu sukar akan menyebabkan siswa menjadi putus asa dan tidak mempunyai semangat untuk mencoba lagi karena di luar jangkauannya menurut" (Arikunto, 2013:222).

Besarnya indeks kesukaran berkisar antara 0,00 sampai dengan 1,00. Soal yang memiliki indeks kesukaran 0,00 menunujukkan bahwa soal tersebut terlalu sukar, karena seluruh testi tidak mampu menjawab soal dengan benar. Sedangkan soal yang memiliki indkes kesukaran 1,00 menunjukkan bahwa soal tersebut terlalu mudah, karena seluruh testi menjawab dengan benar butir tes yang tersedia.

Setelah indeks kesukaran yaitu ke tahap uji daya beda soal adalah kemampuan sesuatu soal untuk membedakan antara siswa yang pandai (berkemampuan tinggi) dengan siswa yang bodoh (berkemampuan rendah) menurut Arikunto (2013:226). Derajat daya pembeda (DP) suatu butir soal dinyatakan dengan indeks diskriminan yang bernilai $-1,00$ sampai dengan 1,00. Apabila indeks diskriminasi makin mendekati nilai 1,00 ini berarti daya pembeda soal akan semakin baik, begitu juga sebaliknya, jika indeks diskriminasi suatu soal mendekati nilai 0,00 maka daya pembeda soal tersebut sangat jelek. Indeks diskriminasi butir soal bernilai negatif (antara 0,00 sampai 1,00) ini berarti kelompok teste kurang mampu banyak yang menjawab benar, sebaliknya banyak teste yang pintar menjawab salah. Sedangkan jika suatu butir soal memiliki indeks diskriminasi 0,00 berarti soal tersebut tidak memiliki daya pembeda.

Sebagai langkah awal menghitung daya pembeda, seluruh testee dikelompokkan menjadi dua kelompok, yaitu kelompok atas dan kelompok bawah. Proses penentuan kelompok atas dan kelompok bawah dari testee adalah dengan cara mengurutkan skor setiap testee, dari skor tertinggi sampai skor terendah. Untuk kelompok kecil (kurang dari 100) penentuan kelompok atas dan kelompok bawah tersebut biasanya hanya diambil dua kutubnya saja, yaitu 50\% skor teratas sebagai kelompok atas dan 50\% skor terbawah sebagai kelompok bawah (Arikunto, 2015:227).

Metode atau teknik analisis data merupakan statistik yang membahas cara-cara penggunaan statistik salah satunya untuk keperluan penelitian. Nilai post test didapatkan dari dua kelompok kelas, yaitu kelas eksperimen dan kelas kontrol yang menjadi sampel penelitian. Analisis hasil post test sesuai dengan analisis yang dipergunakan, dengan terlebih dahulu data yang didapat dari dua kelompok tersebut dicari uji-t yang dinormalisasi dengan menggunakan rumus kolmogorov smirnov.

Uji Homogenitas dilakukan untuk menunjukkan bahwa perbedaan yang terjadi pada uji hipotesis benar-benar terjadi akibat adanya perbedaan varians antar kelompok, bukan sebagai akibat perbedaan dalam kelompok. Uji homogenitas dapat dilakukan apabila kelompok data tersebut berdistribusi normal.

\section{ANALISIS DAN PEMBAHASAN}

Deskripsi data hasil penelitian ini menggunakan rancangan nonequivalent control group design yang dianalisis menggunakan uji-t. objek yang diteliti adalah hasil belajar pengetahuan IPA dengan berbantuan media lingkungan dan pembelajaran konvensional. Data yang diperoleh dalam penelitian ini dikelompokkan menjadi dua yaitu : (1) data hasil belajar pengetahuan IPA kelompok eksperimen, (2) data hasil belajar pengetahuan IPA kelompok kontrol.

Kelompok eksperimen dalam penelitian ini setelah diberikan pretest dilanjutkan dengan diberikan perlakuan melalui model pembelajaran discovery learning dengan berbantuan media lingkungan sebanyak 6 kali, pada akhir penelitian siswa diberikan post test untuk memperoleh data hasil belajar pengetahuan IPA. Kemudian skor post test dicari kolmogorov smirnov yang dinormalisasi dari selisih hasil post test dan hasil pre test. Pengujian asumsi pada penelitian ini menggunakan statistik inferensial yang meliputi uji normalitas sebaran data dan uji homogenitas varians. Uji normalitas sebaran data dan uji homogenitas varians merupakan uji prasyarat sebelum melakukan pengujian hipotesis.

Untuk menyajikan data kedalam tabel distribusi frekuensi, terlebih dahulu menentukan rentangan skor dan kelas interval. Berdasarkan hasil perhitungan diperoleh rentang skor 12, banyak kelas sebesar 6,18 dibulatkan menjadi 6 dan panjang kelas interval sebesar 2. Hasil perhitungan tersebut selanjutnya digunakan dalam pembuatan tabel distribusi frekuensi data post-test hasil belajar IPA siswa kelompok eksperimen yang disajikan pada tabel berikut. 
Tabel 5. Distribusi Frekuensi Skor Post-test Kelompok Eksperimen

\begin{tabular}{llllll}
\hline Interval & Batas Bawah & Titik Tengah (X) & f. Absolut (f) & f. Kumulatif & f(X) \\
\hline $13-15$ & 12.5 & 14 & 2 & 2 & 26 \\
\hline $16-18$ & 15.5 & 17 & 7 & 9 & 121 \\
\hline $19-21$ & 18.5 & 20 & 9 & 18 & 180 \\
\hline $22-24$ & 21.5 & 23 & 16 & 34 & 368 \\
\hline $25-27$ & 24.5 & 26 & 3 & 37 & 75 \\
\hline $28-30$ & 27.5 & 29 & 37 & & 770 \\
\hline Jumlah & & & & 37 & 0 \\
\hline
\end{tabular}

Kemudian data hasil belajar IPA kelompok eksperimen disajikan ke dalam bentuk grafik polygon, seperti pada gambar berikut.

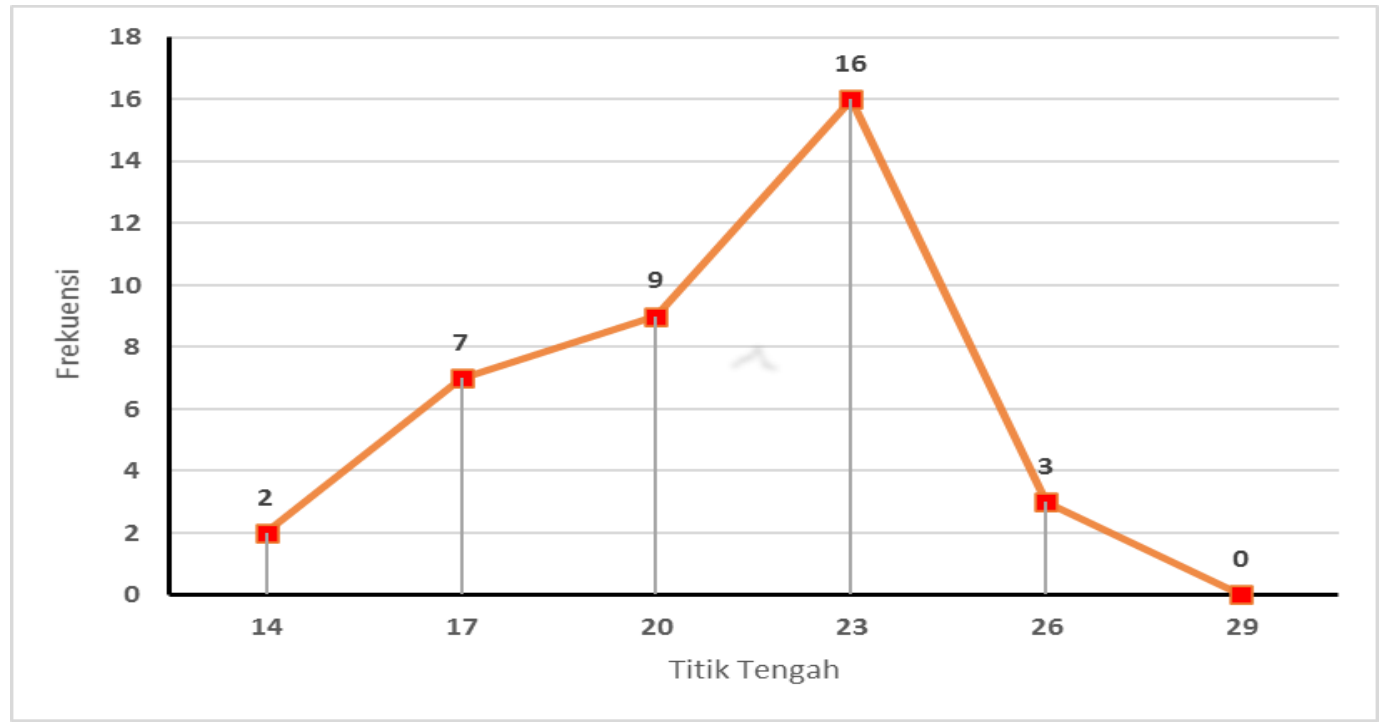

Gambar 1 Grafik Poligon Data Hasil Belajar Kelompok Eksperimen

Setelah pembelajaran berlangsung dengan diberikannya perlakuan melalui pembelajaran konvensional sebanyak 6 kali pada kelompok kontrol, diakhir penelitian siswa diberikan posttest untuk memperoleh data hasil belajar pengetahuan IPA. Kemudian skor posttest dicari kolmogorov smirnov yang dinormalisasi dari selisih hasil post test dan hasil pre test.

Untuk menyajikan data kedalam tabel distribusi frekuensi, terlebih dahulu menentukan rentangan skor dan kelas interval. Berdasarkan hasil perhitungan diperoleh rentang skor 11, banyak kelas sebesar 5,92 dibulatkan menjadi 6 dan panjang kelas interval sebesar 1,5 dibulatkan menjadi 2. Hasil perhitungan tersebut selanjutnya digunakan dalam pembuatan Tabel distribusi frekuensi data post-test hasil belajar IPA siswa kelompok kontrol yang disajikan pada Tabel berikut.

Tabel 6. Distribusi Frekuensi Skor Post-test Kelompok Kontrol

\begin{tabular}{llllll}
\hline Interval & Batas Bawah & Titik Tengah (X) & f. Absolut (f) & f. Kumulatif & $\mathbf{f ( X )}$ \\
\hline $12-13$ & 11.5 & 12.5 & 4 & 4 & 49 \\
\hline $14-15$ & 13.5 & 14.5 & 3 & 7 & 43 \\
\hline $16-17$ & 15.5 & 16.5 & 5 & 12 & 83 \\
\hline $18-19$ & 17.5 & 18.5 & 7 & 19 & 130 \\
\hline $20-21$ & 19.5 & 20.5 & 7 & 26 & 142 \\
\hline $22-23$ & 21.5 & 22.5 & 5 & 31 & 112 \\
\hline Jumlah & & 31 & & 559 \\
\hline
\end{tabular}


Kemudian data hasil belajar IPA kelompok eksperimen disajikan ke dalam bentuk grafik polygon, seperti pada gambar berikut.

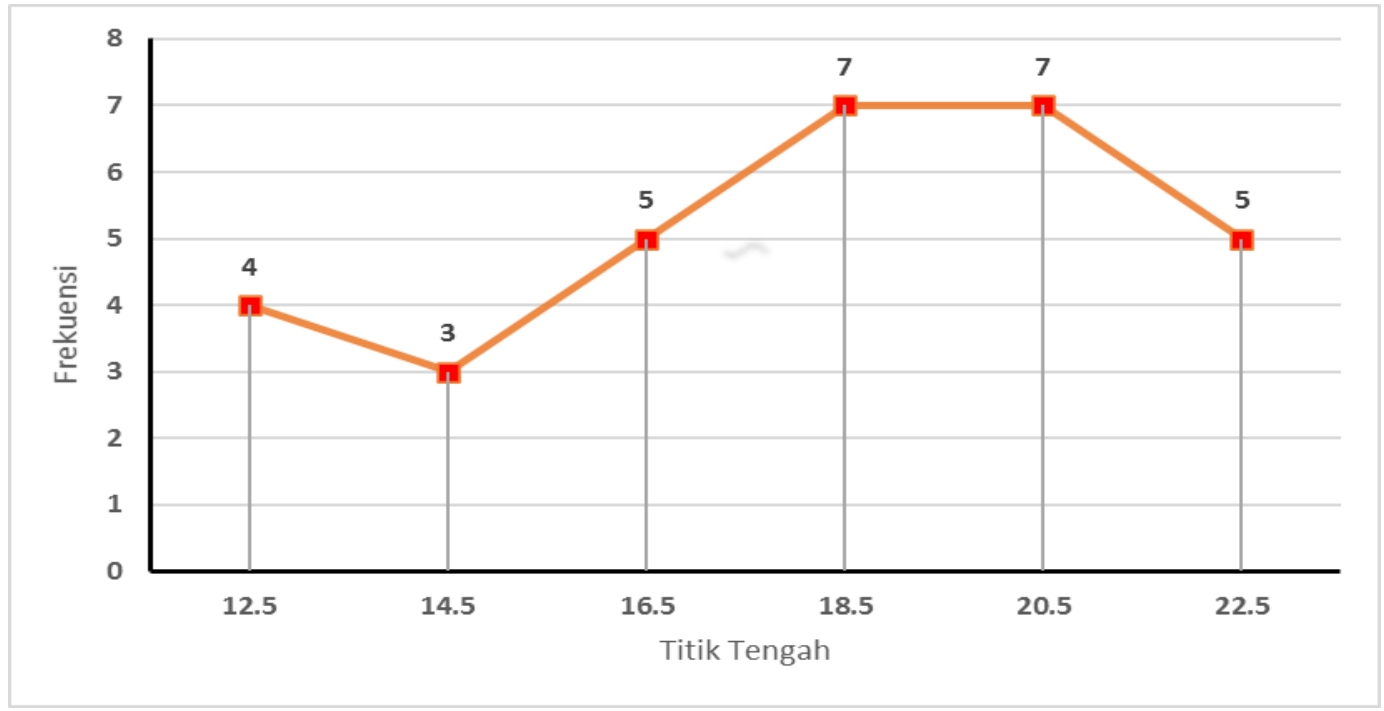

Gambar 2 Grafik Poligon Data Hasil Belajar Kelompok Kontrol

Pengujian asumsi pada penelitian ini menggunakan statistik inferensial yang meliputi uji normalitas sebaran data dan uji homogenitas varians. Uji normalitas sebaran data dan uji homogenitas varians merupakan uji prasyarat sebelum melakukan pengujian hipotesis.

Uji normalitas sebaran data yang digunakan dalam penelitian ini menggunakan teknik KolmogorovSmirnov, dengan kriteria pengujian pada taraf signifikansi $5 \%$ yaitu apabila nilai $|\mathrm{Ft}-\mathrm{Fs}| \leq$ nilai $\mathrm{f}_{\text {tabel }}$ Kolmogorov-Smirnov, maka data berdistribusi normal dan begitu pula sebaliknya apabila nilai $|\mathrm{Ft}-\mathrm{Fs}|>$ nilai $\mathrm{f}_{\text {tabel }}$ Kolmogorov-Smirnov artinya data tidak berdistribusi normal. Harga quantil penguji KolmogorovSmirnov pada taraf signifikansi $5 \%$ untuk $n=37$ adalah 0,22 .

Uji normalitas sebaran data yang digunakan dalam penelitian ini menggunakan teknik KolmogorovSmirnov, dengan kriteria pengujian pada taraf signifikansi $5 \%$ yaitu apabila nilai $|\mathrm{Ft}-\mathrm{Fs}| \leq$ nilai $\mathrm{f}_{\text {tabel }}$ Kolmogorov-Smirnov, maka data berdistribusi normal dan begitu pula sebaliknya apabila nilai $|\mathrm{Ft}-\mathrm{Fs}|>$ nilai $\mathrm{f}_{\text {tabel }}$ Kolmogorov-Smirnov artinya data tidak berdistribusi normal. Harga quantil penguji KolmogorovSmirnov pada taraf signifikansi 5\% untuk $\mathrm{n}=31$ adalah 0,24. Berikut ini hasil rekapitulasi uji normalitas kelompok eksperimen dan kontrol dijabarkan pada tabel dibawah ini.

Tabel 7. Rekapitulasi Hasil Uji Normalitas Kelompok Eksperimen dan Kelompok Kontrol

\begin{tabular}{llllll}
\hline No. & Kelompok Sampel & $\begin{array}{c}\text { Jumlah } \\
\text { Sampel }\end{array}$ & $\begin{array}{l}\text { Nilai } \\
\mid \text { Ft-Fs } \mid \\
\text { Maksimum }\end{array}$ & $\begin{array}{l}\text { Nilai Tabel } \\
\text { Kolmogorov- } \\
\text { Smirnov }\end{array}$ & Keterangan \\
\hline 1 & Eksperimen & 37 & 0,13 & 0,22 & Berdistribusi Normal \\
\hline 2 & Kontrol & 31 & 0,10 & 0,24 & Berdistribusi Normal \\
\hline
\end{tabular}

Sesuai dengan hasil dari pengujian homogenitas diperoleh nilai $F_{\text {hitung }}=1,06$. Adapun nilai $F_{\text {tabel }}$ pada taraf signifikansi $5 \%$ dengan dk pembilang = $30 \mathrm{dan} \mathrm{dk}$ penyebut $=36$ adalah 1,78 sehingga perbandingan $F_{\text {hitung }}<\mathrm{F}_{\text {tabel }}$ yaitu $1,06<1,78$. Sesuai dengan pengujian tersebut data kelompok kelas eksperimen dan kelompok kelas kontrol memiliki varians yang homogen.

Tabel 8. Rekapitulasi Hasil Uji Homogenitas Varians

\begin{tabular}{llllllll}
\hline No & Kelompok Sampel & Varians & Dk & Fhitung & Ftabel & Keterangan \\
\hline 1 & Eksperimen & 10,15 & 36 & \multirow{2}{*}{1,06} & 1,78 & Homogen \\
\hline 2 & Kontrol & 10,83 & & 30 & & & \\
\hline
\end{tabular}


Berikut adalah hasil rekapitulasi analisis uji-t hasil belajara pengetahuan IPA yang disajikan pada tabel sebagai berikut.

Tabel 9. Rekapitulasi analisis uji-t hasil belajar pengetahuan IPA

\begin{tabular}{|c|c|c|c|c|c|c|c|}
\hline No & Sampel & $\mathbf{N}$ & $\mathbf{d k}$ & Mean & $\mathbf{S}^{2}$ & $t_{\text {hitung }}$ & $t_{\text {tabel }}$ \\
\hline 1 & Kelompok eksperimen & 36 & \multirow{2}{*}{66} & 20,81 & 10,15 & \multirow{2}{*}{3,51} & \multirow{2}{*}{1,99} \\
\hline 2 & Kelompok Kontrol & 30 & & 18,03 & 10,83 & & \\
\hline
\end{tabular}

Berdasarkan uji hipotesis diperoleh hasil pembahasannya yang didapat $t_{\text {hitung }}=3,51$ sedangkan pada taraf signifikansi $5 \%$ dengan $\mathrm{dk}=66$ diperoleh nilai $t_{\text {tabel }}=1,99$ sehingga $t_{\text {hitung }}=3,51>t_{\text {tabel }}=1,99$. Dengan demikian, hipotesis nol $\left(\mathrm{H}_{0}\right)$ ditolak. Hal ini menunjukkan bahwa terdapat pengaruh model pembelajaran discovery learning berbantuan media lingkungan terhadap hasil belajar IPA siswa kelas IV SD Gugus Yos Sudarso Kecamatan Denpasar Selatan Tahun Ajaran 2019/2020..

\section{KESIMPULAN}

Berdasarkan hasil analisis data hasil belajar pengetahuan IPA pada kelompok sampel diperoleh thitung= 3,51 sedangkan pada taraf signifikansi 5\% dengan derajat kebebasan $(\mathrm{dk})=66$ diperoleh nilai ttabel= 1,99. Karena thitung $>$ ttabel $(3,51>1,99)$ maka Ha yang berbunyi terdapat perbedaan yang signifikan hasil belajar pengetahuan IPA antara kelompok siswa yang dibelajarkan dengan model discovery learning dengan berbantuan media lingkungan dengan kelompok siswa yang dibelajarkan dengan pembelajaran konvensional pada siswa kelas IV SD Gugus Yos Sudarso Kecamatan Denpasar Selatan Tahun Ajaran 2019/2020 diterima dan H0 yang berbunyi tidak terdapat perbedaan yang signifikan hasil belajar pengetahuan IPA antara kelompok siswa yang dibelajarkan dengan model discovery learning dengan berbantuan media lingkungan dengan kelompok siswa yang dibelajarkan dengan pembelajaran konvensional pada siswa kelas IV SD Gugus Yos Sudarso Kecamatan Denpasar Selatan Tahun Ajaran 2019/2020 ditolak, sehingga dapat disimpulkan bahwa model discovery learning dengan berbantuan media lingkungan berpengaruh terhadap hasil belajar pengetahuan dalam pembelajaran IPA Kelas IV SD Gugus Yos Sudarso Kecamatan Denpasar Selatan Tahun Ajaran 2019/2020. Adapun saran yang dapat disampaikan kepada berbagai pihak sebagai berikut. (1) kepada kepala sekolah agar memberi kesempatan kepada guru - guru untuk menerapkan model - model pembelajaran yang inovatif salah satunya model pembelajaran discovery learning berbantuan media lingkungan serta menyediakan media ataupun alat - alat yang mendukung proses pembelajaran dikelas untuk meningkatkan hasil belajar. (2) kepada kepala sekolah agar dapat menggunakan hasil penelitian ini sebagai pendukung sumber belajar guru dalam meningkatkan kualitas pembelajaran dengan menciptakan variasi pembelajaran yang menyenangkan di sekolah melalui model discovery learning berbantuan media lingkungan sehingga sekolah mampu menghasilkan siswa yang berkualitas. (3) kepada peneliti lain yang berminat untuk mengadakan penelitian lebih lanjut tentang model pembelajar discovery learning berbantuan media lingkungan agar memperhatikan kendala - kendala yang dialami dalam penelitian ini sebagai bahan pertimbangan untuk perbaikan dan penyempurnaan penelitian yang akan dilaksanakan.

\section{DAFTAR PUSTAKA}

Agung, A. A. G. (2014). Buku Ajar Metodologi Penelitian Pendidikan, Edisi 2, Cetakan Pertama. Singaraja: Aditya Media Publishing.

Arikunto, S. (2013). Dasar-Dasar Evaluasi Pendidikan. Jakarta: Bumi Aksara.

Arikunto, S. (2015). Dasar - dasar Evaluasi Pendidikan Edisi Kedua. Jakarta: Bumi Aksara. Arikunto, S. (2016). Prosedur Penelitian Suatu Pendekatan Praktik. Jakarta: PT. Rineka Cipta.

Efendi, M. (2013). Pengantar Psikopedagogik Anak Berkelainan. Jakarta: PT Bumi Aksara.

Nurdin, S., \& Andriantoni. (2016). Kurikulum dan Pembelajaran. Jakarta: PT. Raja Grafindo Persada. 
Setyosari, P. (2015). Metode Penelitian Pendidikan dan Pengembangan Edisi Ke Empat. Jakarta: PT Rineka Cipta.

Sugiyastini, W., \& Dkk. (2013). Pengaruh Model Pembelajaran Berbasis Proyek Terhadap Kemampuan Berpikir Kreatif Siswa Pada Mata Pelajaran IPA Kelas V SD Gugus V Banjar. Jurnal Mimbar PGSD, $1(3)$.

Sugiyono. (2011). Metode Penelitian Pendidikan Pendekatan Kuantitatif, Kualitatif, dan R\&D. Bandung: Alfabeta.

Sugiyono. (2015). Metode Penelitian Kuantitatif Kualitatif dan R\&D. Bandung: Alfabeta.

Sugiyono. (2017). Metode Penelitian Pendidikan (Pendekatan Kuantitatif, Kualitatif, dan R \& D). Bandung: Alfabeta..

Sugiyono. (2018). Metode Penelitian Pendidikan (Pendekatan Kuantitatif, Kualitatif, dan R \& D). Bandung: Alfabeta.

Susilowati, D. (2010). Pengembangan Subject Spesific Pedagogy untuk Pembelajaran IPA Terintegrasi Menggunakan Model Project Based Learning, Problem Based Learning, Guided Inquiry untuk Meningkatkan Keterampilan Proses dan Keterampilan Berpikir Kritis (Critical Thinking) Siswa S. Universitas Negeri Yogyakarta. 